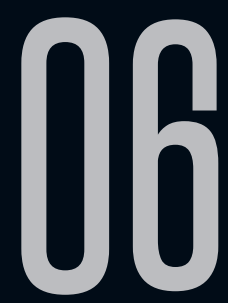

\title{
PELO DE HOMEM, PELE DE BICHO: MURILO RUBIÃO E A RE-CONFIGURAÇÃO DO FANTÁSTICO
}

Marília Westin O. Garcia (USP) Roberto Zular (USP)

Recebido em 30 jul 2020. Aprovado em 02 set 2020.
Marília Westin 0. Garcia é Mestra em Teoria Literária e Literatura Comparada pela FFLCH - USP. Áreas de interesse de pesquisa: literatura e antropologia, literatura fantástica, Murilo Rubião.

Lattes: http://lattes.cnpq.br/1252753562004358

Roberto Zular é Doutor em Letras - Estudos linguísticos e tradutológicos em Francês. Professor titular do departamento de Teoria Literária e Literatura Comparada. FFLCH - USP.

Lattes: http://lattes.cnpq.br/2846581245412905

Resumo: O presente artigo, baseado na dissertação "Corpos à deriva: literatura e animalidade em Murilo Rubião", busca apresentar outras possibilidades de leitura do fantástico. No cruzamento entre literatura e antropologia, surge o questionamento das normatividades em jogo nos contos rubianos cujo personagem animal adquire papel de centralidade, abrindo espaço para a investigação das formas de humanidade acionadas pela animalidade, colocadas aqui em posição de centralidade, bem como das suas consequências políticas para o fazer literário.

Palavras-chave: Literatura fantástica; Murilo Rubião; Animalidade; Perspectivismo. 
Abstract: This article, based on my dissertation "Bodies adrift: literature and animality in the works of Murilo Rubião", aims to present other possibilities of reading the fantastic. In the meeting of literature and anthropology, the questioning of normativity arises demonstrating that it is at stake in the Rubianos' tales which animal character acquires central position. Because of the centrality, the animal character opens up space to investigate ways of humanity triggered by the animality. These ways are placed here in a central position, as well as their political consequences to literary creation.

Keywords: Fantastic literature; Murilo Rubião; Animal study; Perspectivism.

\section{UM OLHO NO PEIXE, OUTRO NO GATO}

Do cruzamento entre literatura e animalidade, cada vez mais presente tanto no âmbito da produção literária quanto no do interesse da recepção crítica, escapa a necessidade de reimaginarmos nosso espaço de existência por meio de outras percepções sensíveis. Se, como apontam Agamben (2017), Lestel (2011) e Haraway (2009), a humanidade só se define como tal a partir do seu contraste com a animalidade e vice-versa, explorar, através da ficção, outras formas de ser animal, também significa explorar outras formas de ser humano e, sobretudo, questionar os limites hierárquicos estabelecidos entre possibilidades de humanidade que escapam dos corpos tradicionais.

Em um contexto no qual modos de existência não hegemônicos têm sido, por um lado, cada vez mais deslegitimados pela parcela conservadora da sociedade e, por outro, conquistado novos espaços no âmbito das manifestações artísticas, a literatura animal 
se configura como um meio potente para performar o conflito entre formas de viver diferentes, obrigadas a conviver em um mundo regido por estruturas de pensamento dicotômicas, que, constantemente, recusam possibilidades de sobredeterminação (MANIGLIER, 2013).

Nesse sentido, a contística rubiana se estabelece como um terreno fértil para que tanto a fluidez - ligada à animalidade, quanto a rigidez - ligada à determinada concepção de humanidade pautada na burocracia e no tradicionalismo cristão, possam ser exploradas na tentativa de conceber um espaço para o humano no qual os corpos sejam livres para assumir outras configurações. Em Murilo Rubião, o ponto de vista validado pelo texto - quando lido a partir das noções de animalidade e humanidade pressupostas por personagens que se disputam e se equivocam no decorrer da narrativa - parece pôr em xeque o corpo do leitor ao fazer emergir, pela sua voz, tanto a animalidade constitutiva do humano, quanto o rastro de humanidade que acompanha o animal. Autor de uma literatura que coloca em tensão os espaços dicotômicos tradicionais a partir da inserção de personagens encarregados de, por meio de suas transformações, questionarem os sistemas vigentes e proporem novas formas de relação entre corpo e mundo, Rubião articula à linguagem lapidada, sobre a qual repousam os seus contos, universos que se tensionam e apontam para a necessidade de repensarmos nossa definição de humano, daí a necessidade de uma proposta de leitura dos contos animalescos de Murilo Rubião a partir da perspectiva enunciativa animal e humana em simultaneidade.

Tal proposta, ancorada na pressuposição da existência de mundos heterogêneos defendida pela antropologia de Viveiros de 
Castro (2015) e Strathern (2014), tem por objetivo criar espaços de visibilidade a partir da necessidade de introjetar as diferenças entre os discursos, sejam eles ficcionais ou não, no lugar de neutralizá-las para forjar a existência de uma univocidade do pensamento.

\section{DEUS NÃO DÁ ASA À COBRA}

Ainda que Rubião coloque em jogo, através da sua literatura, camadas de normatividades muito bem costuradas, capazes de rearticular as experiências a partir da relação entre aquilo que é da ordem da realidade e aquilo que efetivamente tal realidade mobiliza, por conta da necessidade de "adaptar-se ao deslocamento do horizonte de leitura provocado pelo texto muriliano" (CABRAL, 2011, p.23), grande parte dos estudos sobre o autor enfeixam sua obra sobre o prisma do realismo fantástico, tendo como ponto de partida teorias de Todorov e Ceserani ou os preceitos do realismo mágico hispano-americano reestruturados para a descrição da sua especificidade literária.

Para Todorov, o fantástico, enquanto gênero, define-se por meio da hesitação. Assim, seria considerada fantástica toda a literatura na qual "um ser que só conhece as leis naturais, [estivesse] face a um acontecimento aparentemente sobrenatural" (TODOROV, 2010, p.31) e esse acontecimento jamais fosse inteiramente desvendado. Nessa concepção, o fantástico poderia oscilar entre o estranho e o maravilhoso: se o dito "acontecimento sobrenatural" fosse aceito como possível pelos personagens e pelo leitor, estaríamos frente ao maravilhoso; em contrapartida, se tal acontecimento fosse percebido como absurdo, estaríamos frente ao estranho. À 
semelhança da noção de gênero fantástico empregada por Todorov, o realismo mágico também tem como base estrutural a dicotomia real/fantástico; tal qual o subgênero maravilhoso, no realismo mágico o "sobrenatural" convive harmoniosamente com os demais elementos da narrativa, contudo, nele se cruzam os preceitos culturais e históricos dos países latino-americanos aos quais se filiam. Ceserani (2006), por sua vez, define o fantástico como um modo de linguagem que emprega uma série de procedimentos narrativos para criar determinado efeito no leitor. O crítico descola seu conceito de fantástico da noção de gênero e abre espaço para que as narrativas sejam lidas através de parâmetros linguísticos mais apurados, todavia elenca uma série de procedimentos como responsáveis pela impressão do fantástico, restabelecendo certa estrutura formal que sempre contrapõe os efeitos da narrativa a determinado padrão de realidade hierarquicamente mais válida, ainda que esse padrão seja questionado pela própria literatura.

Apesar de tais teorias contribuírem para o traçado de um percurso histórico que caminhe da concepção dos gêneros ao seu questionamento, elas sustentam suas bases no caráter representativo do texto literário, como se para medir a "fantastiquice" (MELLO, 2016) de uma narrativa tivéssemos que estabelecer seu grau de proximidade com o mundo validado como real. Conforme aponta Braulio Tavares (2003, p.7) "[e]m geral, nossa primeira tentativa de definir ou descrever a literatura fantástica se dá de forma negativa. Pensamos nela pelo que ela não é. O fantástico, por essa ótica, é tudo que não é realista", assim, todas as obras que escapam das convenções miméticas de 
representação terminam por serem enquadradas em um mesmo grande gênero, ainda que acionem possibilidades de mundo distintas e se apoiem em estratégias narrativas diferentes.

Todavia, enquanto literaturas como as de Murilo Rubião, mesmo transgredindo as convenções reguladoras, colocam em jogo um "redimensionamento do real" (FRÓIS, 2009) que permite aos críticos atribuírem aos seus contos o estatuto contraditório de realismo fantástico, literaturas que se moldam à determinada realidade também acionam ontologias imaginárias criadas a partir de pressupostos ficcionais e, antes de representarem a realidade, criam novas realidades que podem ou não se encaixar à objetividade da realidade primeira, sendo, portanto, dotadas de certo grau de "fantastiquice".

Essa apreciação da ficção literária coloca um problema para a compreensão da ficcionalidade da obra, pois se, por um lado, o texto é considerado como realista, não parece ser "falso o suficiente" para ser tomado como sendo ficcional - e se, por outro lado, apresenta aspectos que fogem aos parâmetros de verossimilhança estabelecidos por tal juízo, o mundo apresentado é fantástico (ou mágico ou maravilhoso) e, portanto, não pode ser visto como sendo realista. (CABRAL, 2011, p.29)

Esse problema parece se sustentar sobre a corrente confusão entre os pressupostos de existência da ficção e os de existência do universo ficcional criado através da ficção, ou seja, entre o estatuto ficcional da obra literária e a realidade que o universo inventado por ela valida.

Em grande parte de suas narrativas, além de validar um universo ficcional bastante distante daquilo que concebemos 
como realidade, Murilo Rubião aciona, dentro desse universo, ao menos duas ontologias que se chocam a todo o tempo em busca de legitimidade, fazendo-nos "questionar a validade de um modelo ficcional amparado em uma lógica fixa de entendimento dos sentidos da experiência humana" (CABRAL, 2011, p.17) e, arrisco dizer, da experiência animal. Esse mesmo choque ontológico coloca em jogo, a partir da reenunciação literária, a possibilidade de dissenso, abrindo os contos para múltiplas interpretações tecidas a partir dos diferentes "movimentos de invenção de sentido" (ZULAR, 2018, p.2) possibilitados pelos sistemas de mundos em jogo nas narrativas. Longe de apresentarem um mesmo mundo visto por meio de recortes distintos, tais narrativas apresentam mundos distintos vistos a partir dos mesmos signos tornados equívocos que, quando reenunciados, inserem o leitor em um limiar entre possibilidades de significações.

É isso que chamo de dissenso: não um conflito de pontos de vista nem mesmo um conflito pelo reconhecimento, mas um conflito sobre a constituição mesma do mundo comum, sobre o que nele se vê e se ouve, sobre os títulos dos que nele falam para ser ouvidos e sobre a visibilidade dos objetos que nele são designados. (RANCIÈRE, 1996, p.374-375)

Assim, ainda que o pano de fundo das narrativas rubianas seja a "fantastiquice", capaz de propor novos enlaçamentos de real, o que está em jogo é antes um "conflito sobre a própria configuração do sensível" (RANCIÈRE, 1996, p.373). Tal característica da obra já havia sido observada por Schwartz (1981, p.25), que reconhece, nos contos de Murilo Rubião, "uma oposição entre as 
personagens, a partir de suas visões de mundo diametralmente opostas". Contudo, os estudos sobre o autor pouco consideram esse aspecto, colocado em segundo plano para trazer à tona desde análises das narrativas a partir das respectivas correlações epigráficas ${ }^{1}$, até a compreensão do fantástico como um discurso social crítico à sociedade ${ }^{2}$, passando por releituras do gênero fantástico a partir da transgressão proposta pelo autor ${ }^{3}$. Ainda que todas essas possibilidades de leitura sejam válidas e, sobretudo, essenciais para a compreensão da obra rubiana, deixam escapar a complexa tensão ontológica em jogo nas narrativas por alinharem o olhar a apenas uma das possibilidades de mundos fornecidas pelo texto.

Uma vez que, nos contos de Rubião, o sentido não é mais um dado fornecido nem pela ancoragem da literatura a um conceito prévio de realidade com base na falsa sensação de estabilidade dos signos, nem pela solidez ontológica tecida no interior dos contos, o desafio de leitura da obra rubiana está em validarmos, ao mesmo tempo, as muitas possibilidades de mundos, contrariando a tendência a assumir como real o que nos parece mais possível, e propondo articulações entre os contextos através da linguagem que, segundo Roberto Zular, "é parte dessa variabilidade das coisas e um modo de estabelecer relações entre o ato de sua instauração e os mundos que coloca em jogo nesse ato" (ZULAR, 2018, p.2).

1 SCHWARTZ, Jorge (1981). Murilo Rubião: a poética do uroboro. São Paulo: Ática.

2 OLIVEIRA, Acauam Silvério de (2009). Os descaminhos do mito: Formação históricosocial transfigurada em fantástico na ficção de Murilo Rubião. 142f. Dissertação (Mestrado) - Curso de Letras, Universidade Federal de São Paulo, São Paulo.

3 FRÓIS, Wílson Barreto (2009). Murilo Rubião e o redimensionamento do real. $108 \mathrm{f}$. Dissertação (Mestrado) - Curso de Letras, Pontifícia Universidade Católica de Minas Gerais, Belo Horizonte. 
A título de exemplo, se em "Teleco, o coelhinho" temos, do ponto de vista de Barbosa, um homem em corpo de canguru, há também, do ponto de vista do narrador, um coelho que, sob pele de canguru, finge ser homem.

Desse modo, a literatura de Murilo Rubião, ao nos fazer transitar entre perspectivas pela forma singular como opera a construção da realidade interna à obra, abre um sulco em nossas noções de verdade e nos convida a questionar a univocidade do conceito de real e, junto a ela, a nossa noção de humano. Se, conforme observa Iser (1999, p.41), "na leitura pensamos os pensamentos de um outro, pensamentos que - independentemente de quem quer que seja, representam em princípio uma experiência estranha", quando em contato com os contos rubianos que operam por meio da animalidade, para além de pensarmos os pensamentos de um outro, abrimos o espaço do pensar para ser ocupado por novas acoplagens entre corpos e mundos.

Isso acontece porque, como observa Alexandre Nodari (2015), a experiência ficcional literária coloca em jogo mais de uma possibilidade de realidade em simultâneo, de modo que aquelas oferecidas pela realidade ficcional se cruzam com aquelas oferecidas pela realidade externa à obra e fazem com que o leitor especule e ressignifique tanto o texto lido como a própria existência. Nesse sentido, a experiência literária pode ser compreendida como uma "antropologia especulativa"

mas se a leitura é esse entrecruzamento (fazer o mundo consistir e também desconsisti-lo, dando consistência a outros mundos descobertos), então ela não se reduz à leitura de textos escritos, 
isto é, à leitura em sentido estrito, mas constitui uma experiência de contato com o mundo e suas diferentes intensidades, uma prática éticopolítica (ou ecológica) de adquirir uma consistência singular, mas sempre fugidia, no encontro com as multiplicidades, um habitat (sempre precário e finito) no cosmos, ou seja, uma experiência de antropologia e cosmografia, uma antropologia especulativa. (NODARI, 2015, p.78)

Calcada no movimento da virada ontológica, a antropologia aqui em jogo tem como fundamento considerar o conceito de mundo do outro não como uma representação diferente de conceitos do nosso mundo e a eles hierarquizados, mas como uma possibilidade que se efetiva por meio da identificação entre o mundo e os sujeitos que o habitam, validando epistemologicamente as realidades vividas por tais sujeitos como experiências que fazem surgir outros mundos possíveis, os quais, na literatura rubiana, sempre se contrapõem entre si e ao nosso. As teorias de Viveiros de Castro (2015) e Strathern (2014) têm papel fundamental nessa virada, pois torcem o próprio espaço da antropologia ao proporem formas de análise que deem conta da "descolonização permanente do pensamento" (CASTRO, 2015, p.20), seja fundamentando uma etnografia-conceito que rotacione as posições de visibilidade sobre elas mesmas e nos faça questionar qual o ponto de vista temos sobre o ponto de vista do outro, seja analisando a ontologia ficcional do fazer antropológico a partir das premissas que o sustentam, atravessando tal saber com questionamentos potentes estruturados partindo das noções de gênero e de suas associações com os aspectos de natureza e cultura.

Conforme observa Strathern (2014, p.182), em determinado momento da antropologia "[a] diferença entre "nós" e "eles" 
[passa a ser] concebida não como a etapa distinta na progressão evolutiva, mas como uma diferença de perspectiva. "Eles" não visualizavam o mundo através dos mesmos quadros que "nós"". Nesse sentido, a experiência antropológica, assim como a literária, está fundamentada na correlação entre os elementos de mundos distintos, fazendo com que "o mundo fora do alcance da percepção atual [tenha] sua possibilidade de existência garantida pela presença virtual de outrem por quem ele é percebido" (CASTRO, 2002, p.118), de modo a nos permitir não apenas "imaginar uma experiência, mas experimentar uma imaginação" (CASTRO, 2002, p.123) a partir dos mundos ali acionados. Isso em um movimento de troca de perspectivas que, ainda para Viveiros de Castro (2002, p.123), "envolve uma dimensão essencial de ficção, pois se trata de pôr em ressonância interna dois pontos de vista heterogêneos" ou, no caso dos contos "Teleco, o coelhinho", "Alfredo" e "Os dragões", de Murilo Rubião, ao menos três pontos de vista heterogêneos: o do narrador aparentemente humano, o do protagonista aparentemente animal e o do leitor, que articula ambos ao fazer ressoar, em seu corpo ao mesmo tempo animal e humano, as vozes dissonantes acionadas na leitura.

Nesse sentido, a crise da representação antropológica, embasada na ideia de que a diferença entre os sujeitos se dá por conta das concepções de mundo e não simplesmente por conta da maneira como esse mundo é representado, aparece na esteira da crise da univocidade linguística, pois antes de perceber a diferença entre o nosso mundo e o mundo dos outros, foi necessário adquirir a consciência de que a própria linguagem é atravessada, interna e externamente, por diversos regimes de real acionados a partir da 
voz e, embora utilizemos de signos semelhantes para expressar um dito, tais signos são capazes de mobilizar múltiplas afecções e possibilidades de mundo, ou seja, carregam a "relacionalidade de um dizer em que, mais do que significar, cada um comunica quem é" (CAVARERO, 2011, p.11).

Na literatura animal de Murilo Rubião, é no contato entre as múltiplas experiências de mundo propostas pela ficção e as vividas pelo leitor que a linguagem, na sua capacidade de se equivocar e se sobredeterminar, adquire novos contornos e insere as ontologias colocadas em jogo em um limiar relacional no qual se pode ser, ao mesmo tempo, homem e canguru, verbo e dromedário, dragão e amante. Como aponta Cabral a partir de Iser, "[p]or este procedimento, reformula-se o real (pela irrealização da realidade) e se imagina a realidade (mediante a realização do imaginário)" (CABRAL, 2011, p.39), questionando o conceito de humano a partir do acionamento da animalidade que o contém.

Contudo, ainda que, como observamos até aqui, aceitar, através do jogo ficcional, a solidez dos espaços ontológicos colocados em jogo pelos regimes literários seja de suma importância para a leitura de uma obra, raramente tomamos essa solidez como princípio de análise literária, pois partimos do pressuposto de que o saber teórico está muito distante do exercício imaginativo. Assim, literaturas como as de Murilo Rubião são a todo o tempo envolvidas por conceitos que não dão conta de sua potência pelo fato da experiência literária proposta por elas modificar os conceitos desses conceitos, os quais precisam ser re-imaginados durante o processo analítico. 
Nesse sentido, o que a literatura de Rubião coloca em questão são as relações entre modos de fazer e espaços de visibilidade - muitas vezes contraditórias e tensionadas através da coexistência de sistemas ontológicos que se disputam - e não a validade desses sistemas, já legitimados por meio do pacto ficcional. Assim, através de estruturas formais bastante clássicas, permeadas por encadeamentos narrativos lógicos, Rubião insere o leitor em um jogo de continuidade entre a realidade externa e interna. Como observa Arrigucci Jr. (1987, p.146), durante a leitura dos contos rubianos "temos a obrigação de estar dentro, vendo-nos, entretanto, de fora. Mediante esse procedimento, nos transformamos em participantes de um mundo deslocado que, paradoxalmente, é ainda o nosso."

Tal efeito só se faz possível pela complexidade formal que sustenta essa literatura. Envoltos por epígrafes bíblicas, reescritas e metamorfoses, os contos de Murilo Rubião abrem a linguagem para novas possibilidades de sentido que se modificam a cada leitura, por exigirem que o leitor recrie, a cada vez, através de novas acoplagens entre corpo e linguagem que implicam em novas possibilidades ontológicas, as cenas enunciativas ali propostas.

O modificar, em sua literatura, coloca em jogo a obra enquanto estrutura por meio de uma estratégia de eterna continuidade que, conforme observa Schwartz (2016), não produz alterações temáticas e se estabelece como permutações capazes de tornar a linguagem menos hermética. Tais modificações são, sobretudo, responsáveis por refinar as equivocidades em jogo nas narrativas, conforme acontece em "Teleco, o coelhinho". No conto, o conceito de homem passa por uma torção ao ser utilizado para designar um 
canguru que, mesmo sem ser reconhecido a partir de tal conceito pelo narrador, é descrito como tendo pele, pés, mãos, alma e boca, ou seja, por meio de vocábulos tipicamente associados à humanidade e responsáveis pela duplicidade enunciativa que a cena aciona. Ora, ainda que pelos pressupostos ontológicos em jogo no seu mundo, o narrador não valide a humanidade do canguru, ele deixa escapar, pelas frestas da linguagem, a possibilidade de novos cruzamentos de sentido.

Assim, as lacunas das quais falavas Rubião, associadas à primeira instância ao seu processo de reescrita, mais do que propor intercâmbios entre palavras e construções sintáticas, reconfiguram o espaço do texto a partir de novos fios. Quando sobrepostas, as reescrituras dos contos aproximam a construção literária do autor à uma espécie de teia sígnica sobre a qual caminhamos no decorrer da leitura. Partimos e chegamos ao mesmo lugar em todas as versões de um mesmo conto, todavia atravessamos pequenos deslocamentos de sentido no trajeto, que nos permitem perceber outras paisagens, outras derivações responsáveis por encerrar as narrativas rubianas em um ciclo de interminabilidade formal. Também é possível, conforme aponta Arrigucci Jr., associar tais lacunas ao movimento de multiplicação que ocorre no plano temático, do qual derivariam tanto as multiplicações metamórficas dos personagens como a relação entre conto e epígrafe que o precede. "Trata-se, pois, de todo um complexo temático que parece estabelecer com o processo de criação um mesmo movimento unitário e circular. Curiosamente, o movimento é contínuo, mas não progride; multiplica-se, repisando a unidade" (ARRIGUCCI, 1987, p.151). 
Para Carlos de Brito e Mello (2016, p.263-264), por sua vez, a interminabilidade estaria relacionada à busca pela "construção de sentido acerca de nós mesmos, homens ou animais, [que se] mostra como tarefa indispensável e fatigante, revelando-se, mesmo depois de extraordinários e contínuos esforços, interminável". Dessa forma, ainda que ocorra o aparecimento de dragões boêmios, coelhos falantes e dromedários desiludidos, tais personagens, longe de conseguirem alterar a estrutura social pressuposta, devem adequar seu modo de viver ao da humanidade que habita o conto, sob pena de interminável isolamento ou até mesmo morte. Como observa Schwartz (1981, p.38), nos contos rubianos "[s]er diferente implica em transgressão, e o importante é que as formas funcionem; assim, enquanto o homem ${ }^{4}$ não questiona (processo antiindividualizador) e se sujeita às normas (processo massificador), ele tem a garantia de se integrar na sociedade sem provocar rupturas". Assim, o tensionamento constitutivo das narrativas se fundamenta entre modos de vida distintos cujos pressupostos de existência se chocam na tentativa de estabelecer um espaço comum. Contudo, ainda na esteira de Schwartz, dada a tragicidade que permeia o universo rubiano, o resultado sempre é insatisfatório: não se pode conviver com a sociedade na mesma medida em que não se pode escapar dela. Os contos nos quais a animalidade aparece em primeiro plano caminham no mesmo sentido, pois o problema não é que personagens não-humanos existam, falem ou vivam no espaço comum, mas sim que tais criaturas resolvam agir a partir de outras regras, acionar outras ontologias que não a validada pelos narradores, centrada em um

4 No texto, o termo "homem" é utilizado pelo autor como sinônimo de humano. 
antropocentrismo tão cruel quanto o nosso, ainda que operando a partir de outras construções conceituais.

Conforme observa Schwartz (1981) sobre o conto "Os dragões", o que está em jogo na narrativa é antes a necessidade dos habitantes da cidade de inserir os dragões na sociedade do que o questionamento da existência dos dragões que, mesmo presente, perdura por pouco tempo. O mesmo acontece nos contos "Teleco, o coelhinho", em que a verborragia do metamorfo e seu comportamento humano não são questionados até que ele decida ser homem, e em "Alfredo", no qual a presença de um dromedário que fala e usa chapéu espanta menos que seu parentesco com um humano que deseja legitimá-lo como tal. Como pano de fundo dessas tentativas de legitimação de identidades por parte dos personagens, multiplicam-se transformações e temporalidades com o objetivo de propor um avanço, porém, tais multiplicações culminam na repetição incessante de determinada ordem que subjuga a todos aqueles que tentam rompê-la.

A coexistência de muitas camadas ontológicas que acionam diversos regimes de sentido por meio da enunciação parece ser responsável pela rearticulação infinita ou pelo caráter multiplicativo ao qual o texto rubiano está a todo o tempo submetido. Uma vez que tais movimentos de sentido se deslocam a cada nova leitura e carregam em seu interior contextos bastante distintos, vemo-nos diante de um ciclo de inúmeras possibilidades interpretativas, de modo que a variação da experiência de leitura passa a ser a única experiência possível, contrapondo-se à violenta experiência de dominação à qual são submetidos os protagonistas e trazendo aos 
contos possibilidades políticas de encenação que ressignificam o conteúdo das cenas inevitavelmente trágicas para os personagens por elas acionados. Assim, enquanto no universo ficcional das narrativas rubianas o conflito em jogo culmina na destruição da ontologia que propõe modos de existência calcados na possibilidade de variação de corpos, a todo o tempo atravessada pela rigidez autoritária de um mundo no qual não é permitido fluir, os pressupostos da ficção tecidos por Murilo Rubião determinam que o leitor, para dar conta do processo de leitura dos contos, precise fluir entre os corpos por ela mobilizados, propondo uma torção muito complexa entre aquilo que a obra aciona enquanto enunciado e o que ela efetiva no nível da enunciação.

Esse movimento só se faz possível porque, conforme observa Oliveira (2009, p.19), há, nos contos de Murilo Rubião, "uma sobreposição de temporalidades opostas que se tensionam a todo momento". Dentre tais temporalidades está a temporalidade bíblica, embasada nas epígrafes do velho testamento que é, para Rubião "exatamente o mais mitológico, o mais forte, de uma religiosidade violenta" (LOWE, 1979). Dessa violência germinam as relações sociais das narrativas, organizadas à "sombra da bomba atômica" (LOWE, 1979), nas quais progresso e repressão de tudo que representa o outro convivem há muito.

Confirmando esse movimento repetitivo, as epígrafes bíblicas voltam infalivelmente. [...] Ela[s] [são] por assim dizer, o pré-texto, que os textos murilianos multiplicam. Nela[s] sempre se acham o princípio e o fim de todas as histórias. Com relação a ela[s], estes contos [...] são o meio multiplicado. (ARRIGUCCI, 1987, p.151-152) 
Enquanto pré-texto, as epígrafes atuam como mais uma camada ontológica capaz de mobilizar outros regimes de visibilidade e de rearticular o plano de significação da obra, pois a voz grossa e unívoca do deus cristão soberano do velho testamento ecoa sobre a equivocidade característica da obra de Rubião, na qual tanto linguagem lapidada e fundo ficcional não mimético, quanto regimes ontológicos normativos e seres que escapam a qualquer normatividade coexistem em um mesmo universo, permitindo, para falar com Carlos de Brito e Mello (2016, p.270), "a criação de novos recortes de visibilidade que coloca em jogo novas proposições ontológicas" validadas pela enunciação mesmo quando reprimidas pelo enunciado.

Conforme observa Agamben (2017a, p.166), “[o] caráter "pessoal" do sujeito moderno, conceito tão determinante na ontologia da modernidade, tem origem a teologia trinária [...] e nunca se emancipou dela de fato". A ontologia cristã, ainda para o filósofo, é uma teoria do ato que expressa antes a realização de algo do que a realidade em si, pois a existência singular precisa ser efetivada a partir da essência para então ser considerada como tal. A santíssima trindade, nessa leitura, seria então a associação de um único pressuposto essencial a três possibilidades de existência. A grande questão em torno dessa teologia trinária hipostática, ou seja, que se executa por meio da realização performativa, estaria na dificuldade de "conciliar a unidade da essência com a pluralidade das três pessoas" (AGAMBEN, 2017a, p.167). Daí surge a ideia de que, no mundo, as coisas são relativas assim como é relativa a relação entre potência e essência divina. Nesse sentido, a humanidade do humano - que, para a mitologia cristã é a imagem e semelhança do 
divino - e a animalidade dos animais são menos estanques do que aparentam ser. Assim, torna-se mais compreensível a presença de seres híbridos, como leviatã e beemote, na bíblia judaico-cristã.

Contraditoriamente, essa teologia cristã, cuja fluidez atua como coringa para validar a existência da santíssima trindade, passa a ser, quando orientada pelo catolicismo tradicional, pautada no controle e na fixidez das formas e costumes. Tal contradição atua enquanto eixo temático de muitas narrativas de Murilo Rubião, pois o movimento metamórfico da essência que se transmuda em substância, necessário enquanto única possibilidade para a existência do deus cristão e suas pessoas divinas, ainda que factível como possiblidade de ação, nunca chega ao fim desejado. Para Arrigucci (1987, p.153), nos contos de Murilo Rubião "não se tem acesso aos fins e os meios se converteram em fins em si mesmos", assim, ainda que as metamorfoses sejam um lugar comum nas narrativas, nunca se estabelecem como possibilidade de escape da rigidez imposta. Atravessadas pela performatividade absoluta da voz do deus cristão católico, todas as tentativas de singularidade e fluidez, sejam elas essenciais ou substanciais, são negadas aos personagens que furam as regulagens do humano, desencadeando novas sequências metamórficas que se reproduzem infinitamente ou anulando individualidades e transformando tais personagens em peças da maquinaria social até que sejam consumidos por ela.

Faces e nomes escorregadios que se colam ora aqui ora ali, carregados por um mesmo fluxo. E logo também se casa à transformação propriamente dita dos seres, que viram e desviram animais e plantas, numa mesma instabilidade do ser, o que 
implica a questão mais profunda da identidade não fixada. (ARRIGUCCI, 1987, p.151)

A fluidez de identidade à qual os personagens de Murilo Rubião estão sujeitos nem sempre se relaciona propriamente a uma ausência de individualidade. Em alguns contos, a busca pela singularidade leva o indivíduo a uma sequência de transformações. É o caso de Alfredo, protagonista do conto homônimo, que, para se ver livre do sofrimento de estar entre a humanidade, transforma-se em porco. "De início, Alfredo pensou que a solução seria transformar-se num porco, convencido da impossibilidade de conviver com seus semelhantes, a se entredevorarem no ódio. Tentou apaziguá-los e voltaram-se contra ele" (RUBIÃO, 2016, p.108). A tentativa falha, pois ser porco também carregava violência, levando o personagem a se metamorfosear em verbo e, posteriormente, em dromedário. Sob essa última forma, Alfredo segue caminhando pela serra. Em outros contos, no entanto, essa fluidez transforma-se em estratégia adaptativa. Odorico e João, personagens de "Os dragões", são os únicos da espécie que sobrevivem aos maus-tratos humanos. São eles os dragões mais "corrompidos" e também os que mais reproduzem comportamentos da humanidade. Odorico termina assassinado pelo marido da amante, enquanto João busca cada vez mais aumentar sua popularidade. Quando mais jovens, "fugiam, à noite, do casarão e iam se embriagar no botequim" (RUBIÃO, 2016, p.48).

O tensionamento entre o conteúdo da forma, pautado no rigoroso labor em busca da objetividade descritiva, e a forma do conteúdo, marcada pela presença de normatividades díspares metamórficas que se misturam e tentam fluir, ambos presentes 
em muitos dos contos de Murilo Rubião, operam como eco dos cruzamentos ontológicos envolvidos na construção dessas narrativas. Enquanto o caráter estrutural da obra nega a fluidez dos personagens, a força contida na afecção de suas vozes e corpos procura desintegrar a estrutura ali armada. Ora, conforme observa o próprio Rubião, o absurdo, nos seus contos, "é exatamente a repetição contínua dos gestos", gestos esses que, para Agamben (2018) faz aparecer, no contínuo da experiência literária, aquilo de corpo e de ritmo acionado pelo movimento da voz na linguagem.

Embora se repitam, os mesmos gestos voltam em outros corpos que se metamorfoseiam enquanto tentativa de escape do embate constante entre a força autoritária - seja ela divina, formal ou reflexo da época histórica - e a busca por maleabilidade. Ao torcerem o espaço de enunciação por meio do jogo das transformações, os personagens rubianos criam um sujeito que se constrói por meio da relação entre os afetos discursivos acionados e embaralhados pelo gesto rítmico da leitura e as experiências cinestésicas do movimento corpóreo metamórfico, deslocando as noções que separam nossa humanidade da animalidade que nos constitui.

\section{CARA DE UM, FOCINHO DE OUTRO}

Narrado por um professor que sugere interpretações essencialmente antropocêntricas acerca dos animais, a marca da convivência entre a comunidade e os inusitados dragões visitantes de "Os dragões" se dá, em um primeiro momento, pela necessidade de separação hierárquica entre as espécies acompanhada de uma tentativa de domesticação dos visitantes 
por parte da humanidade. A absorção desses animais como membros da sociedade, conforme observa Zagury (1987), só se faz possível quando os dragões rejeitam sua individualidade e passam a replicar comportamentos humanos. No limite, a igualdade de tais animais diante dos demais membros da comunidade funciona como recompensa pelo apagamento de determinada animalidade que, por extrapolar os limites do entendimento humano, parece ser indomesticável.

A ânsia de atribuir características humanas ao dragão faz com que sejam eliminados seus atribuídos "dragonáceos". O homem ignora que "os dragões podem comunicar-se entre si apesar das distâncias que os separam e sem a necessidade de palavras" (cf. BORGES, 1957, p.10 Apud El libro de los seres imaginarios, p.10). (BORGESSCHWARTZ, 1981, p.40)

Depois de aparentemente adaptado à vida na cidade, João, o dragão derradeiro, apaixona-se por uma trapezista de circo, espaço de possibilidade para o exótico na literatura de Murilo Rubião, e desaparece. Se, por um lado, o exotismo circense faz o sistema de mundos operar a partir de novos parâmetros durante os espetáculos, quando longe das cortinas os seus animais são submetidos a crueldades ainda mais violentas do que as comumente infligidas pelo coletivo social. Desse modo, enquanto João desaparece sem deixar rastros que nos permitam compreender de que forma se deu essa experiência, Teleco, personagem de "Teleco, o coelhinho", retorna do circo já perto da morte.

A narrativa tem como protagonista um metamorfo cuja capacidade transformacional e o pertencimento à animalidade, para 
além de serem bem aceitos por seu anfitrião aparentemente humano, configuram-se como o motivo primeiro da hospitalidade. No início do conto, o narrador faz menção de enxotar Teleco por presumir ser ele um menino de rua, mas, ao se deparar com um coelhinho, acolhe-o em sua residência. No conto, o jogo entre as posições humano e animal adquirem estatuto hierárquico mais complexo que em "Os dragões", pois humanos sub-humanizados aparentam merecer menos afeto do que animais que, mesmo falantes, não questionam o seu pertencimento à esfera da animalidade.

No conto, a complicação acontece no momento em que Teleco, na corporalidade de um canguru, procura adentrar o espaço da humanidade ao se declarar homem. Para além de colocar em jogo novas possibilidades conceituais de humano, o protagonista também reconfigura o signo homem ao presumir que tal signo pode ser ocupado por outras corporalidades. Se em "Os dragões" a inserção social dos animais no seio da humanidade servia como paliativo para tornar possível a convivência entre as espécies, de maneira quase oposta, em "Teleco, o coelhinho", a tentativa de pertencimento social realizada pelo canguru que se declara homem culmina na desestabilização das estruturas hierárquicas já muito bem consolidadas pela ontologia narrativa e faz ruir a relação estabelecida entre o protagonista e o narrador.

Tanto em "Os dragões" como em "Teleco, o coelhinho", as transformações metamórficas, sejam elas corpóreas ou não, têm como finalidade aproximar os respectivos metamorfos da humanidade. Em "Alfredo", por sua vez, as mutações do protagonista são motivadas por seu desejo de se afastar do convívio com os humanos. Nesse conto, o tensionamento entre 
as posições de humanidade e animalidade se dá por meio do questionamento da superioridade humana, tida por Alfredo como aquela que propaga crueldade e violência. Ainda que procure novas possibilidades corpóreas que deem conta de aplacar seu sofrimento, Alfredo termina por seguir melancólico sob a forma de um dromedário que, por ter falhado em suas tentativas anteriores, apenas bebe água para se consolar.

Por colocarem em jogo no mínimo dois sistemas ontológicos que percebem animalidade e humanidade a partir de perspectivas diferentes, os três contos operam em um espaço equívoco de sobredeterminações responsáveis por promover indeterminações entre os conceitos de animal e humano enquanto criam uma disputa pela validação dos corpos que, mesmo improváveis e animalescos, são construídos como humanos por meio das acoplagens acionadas pelo processo de enunciação.

A inserção de protagonistas cujos modos de existência se dão a partir de outras noções normativas ou de corporalidades destoantes, que atuam no espaço regulado da humanidade, faz com que novas relações entre as noções de humano e de animal, tornadas fluidas e transversais, venham à tona. Desse modo, vemo-nos diante de um questionamento que relativiza a validade da instituição ontológica pautada na burocracia cotidiana e na repetição das mesmas ações, por meio do questionamento da validade da instituição ontológica pautada na exceção humana.

Isso acontece porque os animais, nos contos de Murilo Rubião, impõem uma lógica na qual, além de serem um ponto de vista, são também o ponto de vista do ponto de vista. Ainda que as 
cenas sejam construídas a partir dos pressupostos do narrador supostamente humano, na interação entre linguagem e voz ressoa mais de um campo enunciativo, que têm como eixo os espaços de visibilidade e gestos ali acionados, pois enquanto em uma ontologia se transformar em humano está associado ao poder dizê-lo ou performá-lo, em outra é a mudança do ponto de vista do narrador que valida ou invalida a humanidade daquele que é observado. Essa duplicidade interior à obra abre espaço para novos cruzamentos entre humanidades e animalidades, o tempo todo atravessados pela inserção de espaços ontológicos exteriores pautados nas múltiplas formas de olhar que carrega o leitor rubiano, cujo corpo ora se acopla ao humano, ora se acopla ao animal e, ainda, ora percebe que, nem humano nem animal, é também ele um ser metamorfo que ocupa o limiar entre essas duas ontologias.

Em vez da relação sujeito-objeto, o leitor, enquanto ponto perspectivístico, se move por meio do campo de seu objeto. A apreensão de objetos estéticos tecidos por textos ficcionais tem sua peculiaridade em sermos pontos de vista movendo-nos por dentro do que devemos apreender. (ISER, 1999, p.12)

A ideia de que o leitor atue enquanto ponto perspectivístico na experiência de leitura nos faz voltar ao campo da antropologia. Tal como os ameríndios de Viveiros de Castro (2015), que só ouvem a língua do bicho quando transformados eles mesmos em bicho e, por conseguinte, inseridos em outro regime de verdade, o sujeito que mergulha no jogo ficcional proposto pela obra literária se vê capturado por uma ontologia diferente daquela que lhe é familiar. Esse sujeito, contudo, consegue operar a partir de mais de uma normatividade em simultâneo. Ainda que diretamente 
envolvido no fluxo transformacional e capturado pelas novas regras ontológicas ditadas pela ficção, o leitor transita entre o mundo de lá e o mundo de cá, traduzindo, à maneira dos xamãs, aquilo que diz o outro regime de verdade.

No processo de tradução transbordam afetos, por isso podemos atribuir a um mesmo texto diferentes perspectivas de leitura. Essas perspectivas obedecem a regulagens estabelecidas no fazer da escrita que permitem ao leitor o trânsito fluido entre os pontos de vista impressos na obra. Nas narrativas de Murilo Rubião, ainda que o narrador detenha a camada do enunciado e seja ele o responsável pelo contar dos contos, a tessitura da camada enunciativa, quando acoplada ao corpo daquele que lê, faz transbordar palavras que acionam o ponto de vista dos protagonistas. Dessa maneira, "[o] que a linguagem diz [do ponto de vista do enunciado] é transcendido por aquilo que ela revela [do ponto de vista da enunciação], e aquilo que é revelado representa seu verdadeiro sentido" (ISER, 1999, p.66).

Ainda que "os signos verbais [ativem] a afeição do leitor necessária para a sua realização" (ISER, 1999, p.40), para dar conta do processo, o leitor rubiano se vê diante de um mise en abyme de pontos de vista orientados por múltiplas ontologias que, muitas vezes, destoam da posição enunciativa do corpo que diz e, ao dizer, transforma-se. Além disso, o que é enunciado por um personagem por vezes aciona o espaço de enunciação validado pelo personagem concorrente, colocando em jogo imagens causadoras de estranhamento por serem frutos de um choque ontológico entre as camadas de sentido dos signos ali impressos. 
É por conta da complexidade estrutural dos contos de Murilo Rubião que a animalidade presente em tais narrativas, para além de propor uma inversão e, a partir dela, tecer críticas à humanidade, faz surgir possibilidades ontológicas capazes de estabelecer novos cruzamentos entre corpos e vozes, tornados fluidos pelo movimento de leitura. No limite, a pele do bicho aciona um processo de devir, pois o que ocorre não é que o humano se torne animal ou que o animal se torne humano, mas sim que ser humano se torne outra coisa que não um enquadre em categorias forjadas e estanques.

Contudo, entre as coisas espantosas e estranhas que compõem o mundo, está a imposição categórica de categorias. Por isso, a tentativa de hierarquização das experiências dos personagens rubianos a partir do seu pertencimento ou não pertencimento à esfera entendida como humana atravessa tanto o enredo como muitas leituras das obras. Ainda que seja importante considerar o fundo alegórico enquanto motor para a primeira leitura das narrativas, é necessário transpor essa barreira e tentar compreender tanto a forma de construção da subjetividade dos personagens não humanos ainda que humanizados e não humanizados ainda que humanos, quanto as consequências do fato de tais personagens, por meio de suas corporalidades destoantes, embaralharem as noções de humanidade e animalidade inicialmente estanques aos olhos de seus narradores.

Nesse sentido, é importante retomar Donna Haraway (2009, p.46), para quem "[a] luta política consiste em ver a partir de ambas as perspectivas ao mesmo tempo, porque cada uma delas revela tanto dominações quanto possibilidades que seriam inimagináveis a partir do outro ponto de vista" e atravessar as 
multiplicações metamórficas acionadas pelos protagonistas com um olhar perspectivístico, na tentativa de confundir as fronteiras ontológicas que sustentam a obra, abrindo uma terceira via de leitura, na qual nem humanidade nem animalidade sejam entendidas como categorias estanques e, portanto, não precisem ser dominadas uma pela outra.

\section{REFERÊNCIAS}

AGAMBEN, Giorgio (2017a). O aberto: o homem e o animal. Rio de Janeiro: Civilização Brasileira.

(2017b). O uso dos corpos. São Paulo: Boitempo.

(2018). "Por uma ontologia e uma política do gesto". Caderno de leituras, (76). Belo Horizonte: Edições Chão da Feira. In https://chaodafeira.com/ catalogo/caderno-n-76-por-uma-ontologia-e-uma-politica-do-gesto/ Acesso em: 28.Jun.2019.

ARRIGUCCI JR., Davi (1987). "Minas, assombros e anedotas (Os contos fantásticos de Murilo Rubião)". In: Enigma e comentário: ensaios sobre literatura e experiência. São Paulo: Companhia das Letras, p.141-165.

CABRAL, Cleber Araújo (2011). Lugares de bruma: coordenadas do imaginário narrativo de Murilo Rubião. 149f. Dissertação (Mestrado) - Curso de Letras, Universidade Federal de Minas Gerais, Minas Gerais.

CASTRO, Eduardo Viveiros de (2002). "O nativo relativo". Mana, Rio de Janeiro, 8(1), 113-148, Abr. 2002. In http://www.scielo.br/scielo.php?script=sci_ arttext\&pid=S0104-93132002000100005 Acesso em: 19.Fev.2019.

(2015). Metafísicas Canibais. São Paulo: Cosac Naify.

CAVARERO, Adriana (2011). Vozes Plurais: filosofia da expressão vocal. Belo Horizonte: Editora UFMG.

CESERANI, Remo (2006). O fantástico. Curitiba: UFPR.

FRÓIS, Wílson Barreto (2009). Murilo Rubião e o redimensionamento do real. 108f. Dissertação (Mestrado) - Curso de Letras, Pontifícia Universidade Católica de Minas Gerais, Belo Horizonte. 
HARAWAY, Donna (2009). "Manifesto ciborgue: ciência, tecnologia e feminismosocialista no final do século XX". In: KUNZRU, Hari. Antropologia do ciborgue: as vertigens do pós-humano. Belo Horizonte: Autêntica Editora, p.33-118.

ISER, Wolfgang (1999). O ato de leitura: uma teoria do efeito estético Vol.2. São Paulo: Editora 34.

LESTEL, Dominique (2011). “A animalidade, o humano e as 'comunidades híbridas'”. In: MACIEL, Maria Esther (Org.). Pensar/escrever o animal: ensaios de zoopoética e biopolítica. Florianópolis: Editora UFSC, p.23-53.

LOWE, Elizabeth (1979). "A opção do fantástico: entrevista com Murilo Rubião". Revista Escrita. São Paulo. IV(29), 24-33. In http://www.murilorubiao.com.br/ entlowe.aspx Acesso em 14.Jun.2019.

MANIGLIER, Patrice (2013). "Manifesto para um comparativismo superior em filosofia". Revista Veritas, Porto Alegre, 58(2), 226-271, maio/ago.

MELLO, Carlos de Brito e (2016). "Mais sombras que silêncio". In: RUBIÃO, Murilo. Obra completa: Edição do centenário. São Paulo: Companhia das Letras, p.254-275.

NODARI, Alexandre (2015). "A literatura como antropologia especulativa". Revista da Anpoll, Florianópolis, 38, 75-85, jan/jun.

OLIVEIRA, Acauam Silvério de (2009). Os descaminhos do mito: Formação histórico-social transfigurada em fantástico na ficção de Murilo Rubião. 142f. Dissertação (Mestrado) - Curso de Letras, Universidade Federal de São Paulo, São Paulo.

RANCIÈRE, Jacques (1996). "O dissenso". In: NOVAES, Adauto (Org.). A crise da razão. São Paulo: Companhia das Letras, p.367-383.

RUBIÃO, Murilo (2016). Obra completa. São Paulo: Companhia das Letras.

SCHWARTZ, Jorge (2016). "O fantástico em Murilo Rubião: uma visita". In: RUBIÃO, Murilo. Obra completa: Edição do centenário. São Paulo: Companhia das Letras, p.251-253.

(1981). Murilo Rubião: a poética do uroboro. São Paulo: Ática.

STRATHERN, Marilyn (2014). "Sem natureza, sem cultura: o caso Hagen". In: O efeito etnográfico e outros ensaios. São Paulo: Cosac Naify, p.23-76. 
TAVARES, Braulio (2003). "Nas periferias do real ou o fantástico e seus arredores". In: TAVARES, Braulio. Páginas de sombra: contos fantásticos brasileiros. Rio de Janeiro: Casa da Palavra, p.7-18.

TODOROV, Tzvetan (2010). Introdução à literatura fantástica. São Paulo: Perspectiva.

ZAGURY, Eliane (1987). "O contista do absurdo". Belo Horizonte, Suplemento Literário, 22(1061), 11, fev.

ZULAR, Roberto. Fiç̧ão como variação de contexto. In https://www.academia. edu/39149593/Fic\%C3\%A7\%C3\%A3o_como_varia\%C3\%A7\%C3\%A30_de_ contexto Acesso em: 04.Fev.2018. 